\title{
Pengaruh Ukuran Perusahaan, Jenis Opini Auditor, Laba/Rugi Operasi, Profitabilitas dan Solvabilitas Terhadap Audit Delay Sub Sektor Rokok yang Terdaftar di Bursa Efek Indonesia
}

\author{
Hari setiono ${ }^{1}$. Rubiyanto ${ }^{2}$ \\ Program Studi Akuntansi, Fakultas Ekonomi, Universitas Islam Majapahit Mojokerto ${ }^{1,2}$ \\ setionohari171167@gmail.com
}

\begin{abstract}
Abstrak
Laporan keuangan dapat dikatakan relevan jika disampaikan tepat waktu. Laporan tepat waktu ini bisa terlihat pada audit delay, yaitu lamanya pelaporan laporan keuangan antara tanggal Neraca sampai dengan tanggal laporan auditor. Tujuan dari pada penelitian ini adalah untuk mengetahui apakah variabel ukuran perusahaan, jenis opini auditor, laba/rugi operasi, tingkat profitabilitas, dan solvabilitas, berpengaruh terhadap audit delay pada perusahaan rokok yang terdaftar di Bursa Efek Indonesia tahun 2011-2017. Jenis penelitian ini adalah penelitian kuantitatif dekstriftip. Dalam penelitian ini peneliti mengguinakan jenis data sekunder yang didapat dari Bursa Efek Indonesia (BEI) dengan mangambil data laporan kuangan. Sedangkan untuk menganalisis data peneliti menggunakan metode analisis regresi linier berganda. Hasil yang diperolah secara simultan penelitian ini menunjukkan bahwa kelima variabel berpengaruh signifikan sebesar $42 \%$ terhadap audit delay. Dan secara parsial dari 5 variabel mempunyai pengaruh terhadap audit delay adalah tingkat profitabilitas dengan nilai signifikansi t 0,018 yaitu kurang dari $0,5 \%$, dan yang lainnya tidak berpengaruh.
\end{abstract}

Kata Kunci : Audit Delay, Jenis Opini Auditor, Laba/Rugi Operasi, Profitabilitas, Solvabilitas

\begin{abstract}
Abstrac
Financial statements can be said to be relevant if the delivery is timely. This timeliness can be seen from audit delay, namely the length of reporting of financial statements between the closing date of the book until the date of the auditor's report. The purpose of this study was to determine the effect of company size variables, auditor opinion types, operating profit / loss, profitability, and solvency levels, on audit delay in cigarette companies listed on the Indonesia Stock Exchange in 2011-2017. This type of research is qualitative descriptive. The type of data used is secondary data obtained from the Indonesia Stock Exchange (IDX) by taking financial statement data. The analysis method uses multiple linear regression analysis. The results obtained in this study indicate that simultaneously the five variables have a significant effect of $42 \%$ on audit delay. And partially from the 5 variables that affect audit delay is the level of profitability with a significance value of $t 0.018$ which is less than $0.5 \%$, while the others have no effect.
\end{abstract}

Keywords: Audit Delay, Type of Auditor Opinion, Operating Profit / Loss, Profitability , Solvability 


\section{PENDAHULUAN}

Menurut Ikatan Akuntan Indonesia (IAI) dalam Kerangka Dasar Penyusunan dan Penyajian Laporan Keuangan (KDPPLK) (2012:20), tujuan dari laporan keuangan yaitu untuk menyediakan informasi yang mempunyai hubungan dengan segala sesuatu tentang keuangan perusahaan yang mempunyai manfaat untuk pemakainya dalam pengambilan keputusan. Laporan keuangan yang dihasilkan perusahaan dan telah dipublikasikan, dapat digunakan sebagai tolak ukur dalam proses penilaian kinerja suatu perusahaan bagi pihak-pihak yang berkepentingan.

Supaya laporan keuangan (financial report) bisa digunakan sebagai dasar pengambilann keputusan, informasi yang disampaikan dalam laporan keuangan tersebut harus mempunyai kualitas. Seperti yang disebutkan dalam Pernyataan Standar Akuntansi Keuangan (PSAK:2009), tentang KDPPLK, bahwa suatu laporan keuangan harus mempunyai 4 (empat) karakteristik yang bisa membuat informasi laporan keuangan tersebut bermanfaat bagi seluruh penggunanya. Keempat karakteristik tersebut adalah bisa dipahami, relevan, keandalan dan bisa dibandingkan.

Menurut Gregory dan Van Horn (dalam Hilmi dan Ali, 2008:11), ketepatan waktu berarti mutu ketersediaan informasi pada saat yang dibutuhkan atau mutu informasi yang baik dilihat dari segi waktu. Jadi semakin cepat informasi laporan keuangan dipublikasikan, maka informasi tersebut menjadi semakin mempunyai manfaat untuk mengambil keputusan. Tetapi sebaliknya jika terjadi penundaan laporan keuangan , dengan demikian informasi yang ada didalamnya akan kehilangan keterkaitan dalam hal pengambilan suatu keputusan.

Lamanya waktu yang dibutuhkan dalam menyelelesaikan audit yang dilakukan oleh auditor dilihat dari perbedaan antara waktu tanggal laporan keuangan dan tanggal opini audit pada laporan keuangan. Perbedaan waktu ini sering disebut audit delay (Subekti dan Widiyanti, 2004:15). Jika waktu bertambah lama audit delay, maka penyampaian laporan keuangan kemungkinan semakin besar keterlambatannya. Bagaimana seharusnya yang dilakukan adalah bagaimana supaya penyampaian laporan keuangan tidak terlambat atau tepat waktu sehingga informasi yang terkandung didalamnya dapat terjaga kerahasiaannya dari pihak-pihak yang tidak berkepentingan. Tetapi jika terjadi keterlambatan pelaporan keuangan maka dapat mengakibatkan manfaat informasi yang disampaikan menjadi tidak akurat.

Laporan Keuangan adalah ringkasan dalam suatu proses pencatatan selama periode tahun buku yang berjalan. Laporan keuangan merupakan bagian dari proses pelaporan keuangan (Baridwan, 2004 : 08). Laporan keuangan memiliki tujuan yaitu memberikan suatu informasi yang mempunyai manfaat sebagai alat pengambilan suatu keputusan. Laporan keuangan suatu perusahaan dapat menyajikan suatu informasi yang bermanfaat bagi penggunanya, jika memenuhi persyaratan yang ditetapkan (Prinsip Akuntansi Indonesia) adalah sebagai berikut : 1) Relevan, 2) Dapat Dimengerti, 3) Objektif, 4) Netral, 5) Tepat Waktu, 6) Dapat Dibandingkan, 7) Lengkap.

Semua perusahaan yang sudah go public pasti akan diwajibkan untuk menyampaikan laporan keuangannya sesuai dengan standart akuntansi keuangan dan yang sudah diaudit oleh seorang auditor. Ketepatan waktu belum tentu menjamin relevansi tapi relevansi tidaklah mungkin tanpa ketepatan waktu. Maka dari itu, ketepatan waktu adalah hal penting pada penyampaian laporan keuangan. Apabila penyampaian informasi tidak tepat waktu akan menimbulkan informasi tersebut tidak mempunyai nilai di dalam mempengaruhi kualitas keputusan. Menurut IAI (2002:22) suatu perusahaan sebaiknya mengeluarkan laporan keuangannya paling lama empat bulan setelah tanggal neraca. 
Auditing adalah Suatu proses pengumpulan dan pemeriksaan bukti yang berkaitan dengan informasi untuk menentukan dan membuat laporan mengenai informasi tentang kegiatan dan kejadian ekonomi (Mulyadi, 2002:9). tujuan audit secara umum atas laporan keuangan adalah untuk memberikan pernyataan pendapat atas kewajaran dalam semua hal yang terdapat pada laporan keuangan tersebut sesuai dengan prinsip akuntansi berlaku umum di Indonesia. Kewajaran laporan keuangan dinilai memakai dasar pernyataan manajemen yang terkandung dalam laporan keuangan..

Standar auditing adalah suatu pedoman umum bagi auditor dalam melakukan audit. Standar auditing mengandung arti sebagai suatu tolak ukur atas mutu jasa auditing. Audit delay adalah lamanya / rentang waktu penyelesaian audit yang diukur dari tanggal penutupan tahun buku sampai dengan tanggal diterbitkannya laporan audit (Wirakusuma, 2008:25). Menurut penelitian OwusuAnsah (2009 : 11), apabila semakin lama waktu penyampaian suatu laporan keuangan atau rentang waktu audit delay makin lama, maka informasi yang terdapat didalamnya akan lebih mudah bocor ke pihak-pihak lain yang tidak menggunakan untuk kepentingan pengambilan keputusan. Hal ini bisa mengakibatkan beredarnya rumor-rumor lain di bursa saham.

Ukuran perusahaan adalah merupakan ukuran besar kecilnya perusahaan yang bias dilihat dan diklasifikasikan dengan berbagai cara antara lain dinyatakan dalam total asset, nilai pasar saham, dan lain-lain. Ukuran perusahaan diukur menggunakan total asset yang diproksi menggunakan logaritma.

Opini audit yaitu merupakan pendapat yang terkandung pada laporan audit yang merupakan pernyataan pendapat auditor terhadap kewajaran suatu laporan keuangan berdasarkan atas audit yang telah dilakukan sesuai dengan standar auditing (Petronila, 2007). Ada empat jenis opini (pendapat) yang diberikan oleh auditor kepada perusahaan. Variabel ini diukur menggunakan dummy

Laporan laba/rugi adalah merupakan suatu laporan yang menunjukkan perbandingan antara pendapatan dan biaya-biaya dalam suatu unit usaha untuk suatu periode tertentu. Laba/rugi operasi diukur dengan menggunakan dummy. Untuk perusahaan yang mengalami rugi diberi kode 1 dan untuk perusahaan yang memperoleh laba diberi kode 0 .

Profitabilitas bisa mempunyau arti sebagai kemampuan perusahaan untuk memperoleh laba atau keuntungan. Profitabilitas Diukur berdasarkan nilai ROA (Return on Asset) yaitu Net Profit dibagi dengan Total Asset.

Merupakan perbandingan anatara jumlah aktiva dengan jumlah hutang. Solvabilitas menggambarkan kemampuan perusahaan untuk membayar seluruh kewajibanya, baik yang berupa hutang jangka pendek maupun jangka panjang. Solvailitas dapat ditunjukan oleh rumus sebagai berikut :

$$
\mathrm{SOLV}=\frac{\text { Total Debt }}{\text { Total Asset }} \times 100 \%
$$

\section{METODE PENELITIAN}

Penelitian ini menggunakan pendekatan kuantitaif, dengan menggunakan pengujian hipotesis, metode kuantitatif merupakan metode yang menggunakan data penelitian berupa angka - angka dan analisis menggunakan statistic (Sugiono, 2011:12). Penelitian ini dilakukan pada perusahaan 
manufaktur pada bidang rokok yang terdaftar di Bursa Efek Indonesia pada tahun 2011-2017. Data yang digunakan adalah sumber data sekunder yang didapatkan melakui website (www.idx.com). Sampel dari penelitian ini diambil dengan menggunakan metode purpose sampling, yang setelah melalui tahap kriteria maka sampel yang digunakan ada 4 (empat) perusahaan rokok yang terdaftar di Bursa Efek Indonesia pada tahun 2011-2017. Perusahaan pada bidang rokok yang memiliki laporan keuangan yang telah diaudit secara lengkap periode 2011 - 2017sebanyak 28.

\section{HASIL DAN PEMBAHASAN}

Tabel 1. Descriptive Statistics

\begin{tabular}{lrrrrr}
\hline & \multicolumn{1}{c}{} & & & \multicolumn{1}{c}{$\begin{array}{c}\text { Std. } \\
\text { Deviation }\end{array}$} \\
\hline Audit Delay & 28 & 60 & 86 & 78.36 & 7.578 \\
Ukuran Perusahaan & 28 & 12 & 18 & 16.35 & 1.644 \\
Profitabilitas & 28 & -22 & 39 & 9.10 & 16.479 \\
Solvabilitas & 28 & -8 & 10 & 1.04 & 3.574 \\
Valid N (listwise) & 28 & & & & \\
\hline
\end{tabular}

Tabel 2. Jenis Opini

\begin{tabular}{llrrrr}
\hline & Frequency & Percent & Valid Percent & $\begin{array}{c}\text { Cumulative } \\
\text { Percent }\end{array}$ \\
\hline Valid & 0 & 3 & 10.7 & 10.7 & 10.7 \\
& 1 & 25 & 89.3 & 89.3 & 100.0 \\
& Total & 28 & 100.0 & 100.0 & \\
\hline
\end{tabular}

Tabel 3. Laba/Rugi

\begin{tabular}{llrrrr}
\hline & Frequency & Percent & $\begin{array}{c}\text { Valid } \\
\text { Percent }\end{array}$ & $\begin{array}{c}\text { Cumulative } \\
\text { Percent }\end{array}$ \\
\hline Valid & 0 & 3 & 10.7 & 10.7 & 10.7 \\
& 1 & 25 & 89.3 & 89.3 & 100.0 \\
& Total & 28 & 100.0 & 100.0 & \\
\hline
\end{tabular}

Sumber : data sekunder diolah, 2018

Tabel tersebut menunjukkan bahwa nilai audit delay adalah antara 60 hari hingga 86 hari dengan rata-rata sebesar 78,35 hari, ini masih di bawah 90 hari yaitu standart yang ditetapkan oleh BAPPEPAM dalam penyampaian laporan keuangan dan standar deviasi sebesar 7,57.

Uji normalitas mempunyai tujuan untuk menguji apakah dalam model regresi, variabel dependen (terikat), variable Independen ( bebas) atas keduanya mempunyai distribusi data normal atau tidak. Normal probability plot, terlihat titik-titik menyebar di sekitar garis diagonal serta penyebarannya mengikuti arah garis diagonal, maka asumsi normalitas terpenuhi. 
Tabel 4. Multikolinearitas

\begin{tabular}{llrr}
\hline \multirow{2}{*}{ Model } & \multicolumn{2}{c}{ Collinearity Statistics } \\
\cline { 2 - 3 } & Tolerance & VIF \\
\hline $1 \quad$ (Constant) & & \\
& Ukuran Perusahaan & .823 & 1.216 \\
& Jenis Opini & .882 & 1.134 \\
Laba/Rugi & .797 & 1.255 \\
& Profitabilitas & .919 & 1.088 \\
& Solvabilitas & .826 & 1.211 \\
\multicolumn{2}{c}{ a. Dependent Variable: Audit Delay } & & \\
\hline
\end{tabular}

Tabel di atas menggambarkan semua nilai VIF di bawah 10 atau nilai tolerance di atas 0,1 yang artinya tidak terdapat gejala multikolinearitas dalam penelitian ini. Uji autokorelasi mempunyai tujuan mengetahui apakah dalam suatu model regresi linier ada korelasi antara kesalahan pengganggu pada periode $t$ dengan kesalahan pada periode $t-1$ (sebelumnya). Pengujian hipotesis penelitian dilakukan untuk menguji hipotesis yang telah dilakukan sebelumnya.

Tabel 5. Coefficients ${ }^{\mathrm{a}}$

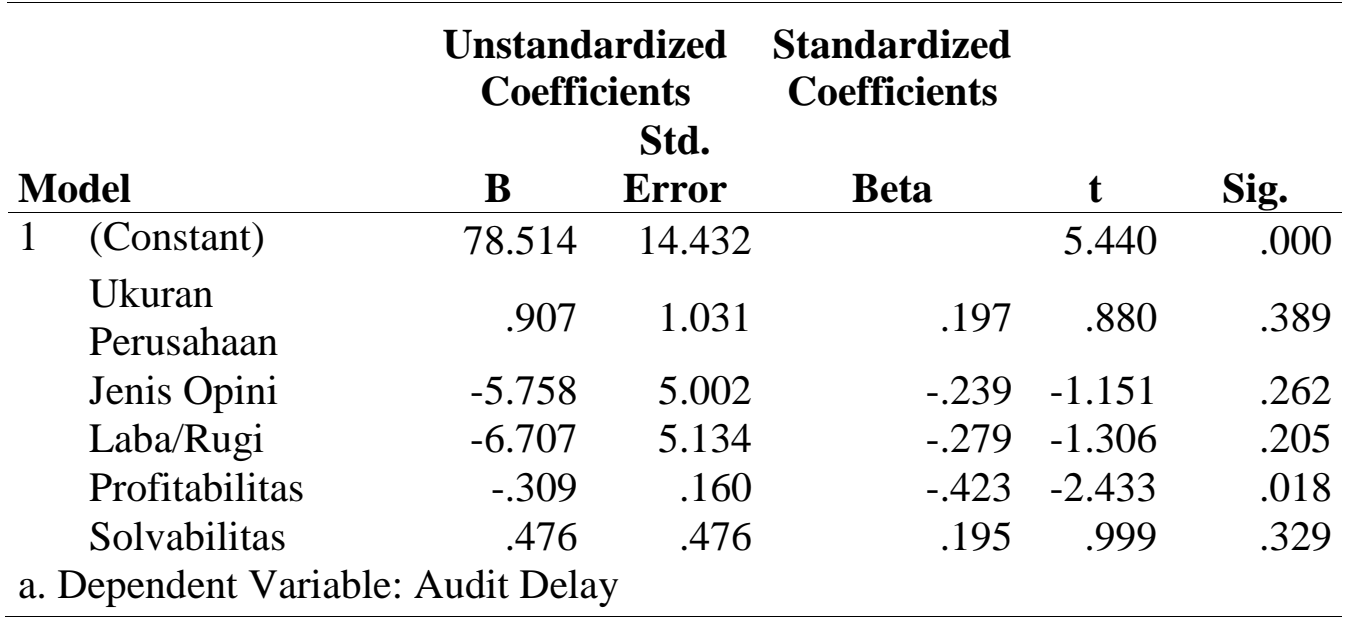

Berdasarkan tabel regresi diatas, dapat diketahui bahwa persamaan regresi yang tebentuk adalah AUDLAY $=78,514+0,907+-5,758+-6,707+-0,309+0,476+\mathrm{e}$

Koefisien determinasi dipakai untuk mengetahui seberapa besar kemampuan variable independen (bebas) menjelaskan variavel dependen (terikat).

Tabel 6. Model Summary ${ }^{b}$

\begin{tabular}{ccrrrr}
\hline Model & R & $\begin{array}{c}\text { R } \\
\text { Square }\end{array}$ & $\begin{array}{c}\text { Adjusted R } \\
\text { Square }\end{array}$ & $\begin{array}{c}\text { Std. Error of } \\
\text { the Estimate }\end{array}$ & $\begin{array}{c}\text { Durbin- } \\
\text { Watson }\end{array}$ \\
\hline 1 & $.420^{\mathrm{a}}$ & .176 & -.011 & 7.619 & 1.830 \\
\hline
\end{tabular}

Dari tampilan output SPSS model summary pada tabel diatas, besarnya nilai $R^{2}$ adalah 0,420 , hal ini berarti $42 \%$. Menunjukan bahwa kemampuan menjelaskan variable independen ukuran perusahaan, jenis opini auditor, laba/rugi operasi, tingkat profitabilitas dan solvabilitas terhadap audit delay sebesar $42 \%$ sedangkan sisanya dijelaskan oleh variable lain diluar empat variable bebas tersebut yang tidak dimasukan dalam model. 
Uji statistik F dipakai untuk melihat pengaruh kelima variabel independen (bebas) terhadap variabel dependen (terikat).

Tabel 7. ANOVA

\begin{tabular}{|c|c|c|c|c|c|}
\hline Model & $\begin{array}{c}\text { Sum of } \\
\text { Squares }\end{array}$ & Df & $\begin{array}{c}\text { Mean } \\
\text { Square }\end{array}$ & $\mathbf{F}$ & Sig. \\
\hline Regression & 375.313 & 5 & 75.063 & 14.405 & $.001^{\mathrm{b}}$ \\
\hline Residual & 1175.115 & 22 & 53.414 & & \\
\hline Total & 1550.429 & 27 & & & \\
\hline
\end{tabular}

a. Dependent Variable: Audit Delay

b. Predictors: (Constant), Solvabilitas, Ukuran Perusahaan, Jenis Opini , Laba/Rugi, Profitabilitas

Tampak bahwa nilai $\mathrm{F}$ hitung pada model penelitian sebesar 14,405 dengan taraf signifikansi 0,001. Nilai signifikansi berada di bawah 0,05 atau F-hitung > F-tabel $(14,405>2,0264)$ artinya bahwa variabel independent secara bersama-sama mempunyai pengaruh signifikan terhadap audit delay.

Uji statistik $\mathrm{t}$ merupakan pengujian yang dipakai untuk melihat pengaruh variabel-variabel independent secara parsial terhadap variabel dependentnya.

Tabel 8. Coefficients ${ }^{\mathrm{a}}$

\begin{tabular}{|c|c|c|c|c|c|}
\hline \multirow{2}{*}{ Model } & \multicolumn{2}{|c|}{$\begin{array}{l}\text { Unstandardized } \\
\text { Coefficients }\end{array}$} & \multirow{2}{*}{$\begin{array}{c}\text { Standardized } \\
\text { Coefficients } \\
\text { Beta }\end{array}$} & \multirow{2}{*}{$\mathbf{t}$} & \multirow{2}{*}{ Sig. } \\
\hline & & $\begin{array}{c}\text { Std. } \\
\text { Error }\end{array}$ & & & \\
\hline $1 \quad$ (Constant) & 78.514 & 14.432 & & 5.440 & .000 \\
\hline Ukuran Perusahaan & .907 & 1.031 & .197 & .880 & .389 \\
\hline Jenis Opini & -5.758 & 5.002 & -.239 & -1.151 & .262 \\
\hline Laba/Rugi & -6.707 & 5.134 & -.279 & -1.306 & .205 \\
\hline Profitabilitas & -.309 & .160 & -.423 & 2.433 & .018 \\
\hline Solvabilitas & .476 & .476 & .195 & .999 & .329 \\
\hline a. Dependent Vari & Delay & & & & \\
\hline
\end{tabular}

Pengujian secara parsial ukuran perusahaan terhadap audit delay menunjukan nilai t hitung sebesar -0.880 dan signifikansi $t$ sebesar 0.389 . Karena $t$ hitung $<$ t-tabel $(-0.880<1.67412)$ dan signifikansi t >5\%, maka secara parsial profitabilitas tidak mempengaruhi secara signifikan terhadap audit delay.

Pengujian secara parsial jenis opini auditor terhadap audit delay menunjukan nilai t hitung sebesar 1,151 dan signifikansi t sebesar 0.262. Karena t hitung lebih $<$ t-tabel $(-1,151<1.67412)$ dan signifansi $\mathrm{t}>5 \%$, maka secara parsial jenis opini auditor tidak mempengaruhi secara signifikan terhadap audit delay.

Pengujian secara parsial laba/rugi operasi terhadap audit delay menunjukan t-hitung sebesar -1,306 dengan signifikasi t sebesar 0,205. Karena t-hitung $<$ t-tabel $(-1,306<1.67412)$ dan signifikasi $\mathrm{t}$ lebih besar dari 5\% maka secara parsial laba/rugi operasi tidak mempengaruhi secara signifikan terhadap audit delay. 
Pengujian secara parsial profitabilitas terhadap audit delay menunjukan nilai t hitung sebesar 2,433 dan signifikansi t sebesar 0.018. Karena t hitung > t-tabel $(2,433>1.67412)$ dan signifikansi t lebih kecil dari 5\%, maka secara parsial profitabilitas mempengaruhi secara signifikan terhadap audit delay.

Pengujian secara parsial solvabilitas terhadap audit delay menunjukan nilai t hitung sebesar 0.999 dan signifikansi t sebesar 0.329 . Karena $t$ hitung $<\mathrm{t}$-tabel $(0.999<1.67412)$ dan siginifikansi $\mathrm{t}$ lebih kecil dari 5\%, maka secara parsial solvabilitas tidak mempengaruhi secara signifikan terhadap audit delay.

\section{KESIMPULAN}

Penelitian ini dimaksudkan untuk menguji secara empiris pengaruh ukuran perusahaan, jenis opini auditor, laba/rugi operasi, dan tingkat profitabilitas terhadap audit delay pada emiten di Bursa Efek Indonesia. Penelitian dilakukan selama tujuh tahun berturut-turut, sedari 2011 hingga 2017 dan mencakup 4 sampel perusahaan rokok . Menggunakan analisis regresi berganda, dimana uji asumsi klasik dilakukan sebelum uji hipotesis, diperoleh beberapa kesimpulan hasil pengujian secara simultan menunjukan bahwa variabel bebas secara serempak mempengaruhi audit delay, sedangkan secara parsial variabel ukuran perusahaan, jenis opini auditor, laba/rugi operasi, tingkat Solvabilitas tidak berpengaruh signifikan terhadap audit delay dan variabel Profitabilitas dan berpengaruh signifikan terhadap audit delay

\section{DAFTAR PUSTAKA}

Amani, F. A. (2016). Pengaruh Ukuran Perusahaan, Profitabilitas Opini Auditor, dan Umur Perusahaan terhadap Audit Delay. Journal Of Economics. Universitas Mercu Buana, Jakarta Alexius, E. V. (2012). Analisis Faktor-Faktor yang Mempengaruhi Ketepatan Waktu Penyampaian Laporan Keuangan. Skripsi Program Sarjana Universitas Lampung.

Carslaw, C.A.P.N. dan Kaplan, S.E. (1991). An Examination of Audit Delay: Further Evidence from New Zealand. Accounting and Business Research. 22(85):21-32.

Dwi, O. (2012). Analisis Faktor yang Mempengaruhi Audit Delay. Journal Of Economics. 9(2): 6568

Halim, V. (2000). Faktor-Faktor Yang Mempengaruhi Audit Delay. Jurnal Bisnis dan Akuntansi. 2(1): 63-75.

Hossain, M.A. dan Taylor. P. J. (1998). An Examination of Audit Delay: Evidence from Pakistan. Working Paper, unpublished.

IAI. (2001). Standar Profesional Akuntan Publik, PT. Salemba Empat, Jakarta.

Ghozali, I dan Ukago, K. (2005). Faktor Faktor Yang Berpengaruh Terhadap Tepat Waktu Pelaporan Keuangan di BEI. Jurnal Maksi. 5:13-33.

Kartika, A. (2009). Faktor-Faktor yang Mempengaruhi Audit Delay di Indonesia (Studi Pada Perusahaan-Perusahaan Pertanian yang Terdaftar di Bursa Efek Jakarta). Jurnal Bisnis dan Ekonomi. 16(1):1-17

Mulyadi. (2014). Auditing. Jakarta: Salemba Empat

Nurmiati. (2015). Faktor-Faktor Yang Mempengaruhi Ketepatan Waktu Pelaporan Keuangan. Jurnal Fakultas Ekonomi Dan Bisnis Universitas Mulawarman

Owusu, Stephen dan Ansah. (2000). Timeliness of Corporate Financial Reportingin Emerging Capital Market: Empirical Evidence Fram The Zimbabwe Stock Exchange. Journal Accounting and Business. 30:241. 
Purwanto, E. A. dan Sulistyastuti. D. R. (2011). Metode Penelitian Kuantitatif. Gava Media : Yogyakarta.

Soetedjo, .S. (2006). Faktor-Faktor Yang Mempengaruhi Audit Delay Log (ARL). 9(2):77-92.

Subekti, I. dan Widiyanti, N.W. (2004). Faktor-Faktor Yang Berpengaruh Terhadap Audit Delay di Indonesia. Simposium Nasional Akuntansi VII:991-1002

Utami, W. (2006). Analisis Audit Delay Kajian Empiris di Bursa Efek Jakarta. Unpublished thesis, Universitas Mercu Buana, Jakarta 